\title{
Bladder Cancer Detection and Monitoring: Assessment of Urine- and Blood-Based Marker Tests
}

\author{
Steve Goodison - Charles J. Rosser • \\ Virginia Urquidi
}

Published online: 12 March 2013

(C) The Author(s) 2013. This article is published with open access at Springerlink.com

\begin{abstract}
Bladder cancer is one of the most prevalent cancers worldwide, but the treatment and management of this disease can be very successful if the disease is detected early. The development of molecular assays that could diagnose bladder cancer accurately, and at an early stage, would be a significant advance. Ideally, such molecular assays would be applicable to non-invasively obtained body fluids, and be designed not only for diagnosis but also for monitoring disease recurrence and response to treatment. In this article, we assess the performance of current diagnostic assays for bladder cancer and discuss some of the emerging biomarkers that could be developed to augment current bladder cancer detection strategies.
\end{abstract}

\section{Introduction}

Bladder cancer $(\mathrm{BCa})$ is among the five most common malignancies worldwide. There are over 70,000 new cases of BCa each year in the United States alone [1]. The most common form of $\mathrm{BCa}$ in Western countries is transitional cell carcinoma (TCC), constituting approximately $95 \%$ of all cases [2]. Risk factors associated with the development of $\mathrm{BCa}$ include carcinogens in tobacco smoke, and to a lesser extent exposure to chemical compounds in the chemical and rubber industries. The disease has a five times higher prevalence among men than women, and the median age at diagnosis is 65 years.

At diagnosis, the majority ( $80 \%$ ) of cases present with non-muscle-invasive papillary tumors (stages pTa or pT1),

S. Goodison $(\bowtie) \cdot$ C. J. Rosser · V. Urquidi

Cancer Research Institute, MD Anderson Cancer Center

Orlando, 6900 Lake Nona Blvd, Orlando, FL 32827, USA

e-mail: steven.goodison@orlandohealth.com and these have a much more favorable prognosis than those that show evidence of muscle invasion at the time of detection. If detected early, the 5-year survival rate for $\mathrm{BCa}$ is approximately $94 \%$, so timely intervention can dramatically increase the probability of patient survival. Radical surgery is required for muscle-invasive lesions, but non-muscle-invasive $\mathrm{BCa}$ can be treated through transurethral resection of the tumor. However, the major clinical problem is that more than $70 \%$ of patients with $\mathrm{Ta} / \mathrm{T} 1 \mathrm{BCa}$ will have disease recurrence within 2 years of treatment. Extensive long-term surveillance and repeated surgical intervention is needed to prevent progression of early-stage tumors to the more lethal invasive disease. When the high recurrence rate of $\mathrm{BCa}$ is taken into consideration, there are approximately 500,000 cases of active BCa in the US [3], and it is one of the most prevalent cancers worldwide.

For initial clinical diagnosis of $\mathrm{BCa}$, the gold standard remains cystoscopic examination of the bladder coupled with voided urine cytology (VUC), the cytologic examination of cellular material present in the urine [4-6]. Cystoscopy is an uncomfortable and costly invasive procedure that may require anesthetization of the patient. The technique enables visualization of the bladder lining and biopsy of suspicious lesions for histopathological diagnosis and staging. Evaluation by VUC relies on the microscopic visualization of shed cancer cells in voided urine. The technique performs well with high-grade and high-stage tumors (T2-T4), but because Ta-T1 tumors shed fewer cancer cells into the urine, the sensitivity of VUC for the detection of early-stage tumors is low, ranging from only 20 to $40 \%[6,7]$. Coupled with the fact that VUC is prone to interobserver variation [8], it is understandably not seen as a standalone test for application in a potential $\mathrm{BCa}$ clinical investigation. After initial treatment of non-muscle-invasive tumors, $\mathrm{BCa}$ patients are placed under 
continued surveillance, with routine examinations performed by cystoscopy and cytology in order to achieve early detection of new tumor development. The regimen is typically cystoscopy every 3 months for 2 years, then every 6 months for 2 years, and then every year thereafter. Consequently, the development of non-invasive assays that can reduce the need for cystoscopy would be of tremendous benefit to both patients and the healthcare system. For $\mathrm{BCa}$, the accessibility of urine in this context is a major advantage. The sample can be obtained noninvasively (avoiding patient discomfort and potential complications from an invasive procedure), copious amounts of sample can be obtained for analysis, and repeat sampling is easily achievable. While there have been efforts to identify serum-based biomarkers for $\mathrm{BCa}$ detection, this is less well developed, and there are currently no blood-based tests available for detection. The analysis of blood-based biomarkers may have more utility in prognosis or therapeutic decisions [9-11]. In this review, we will assess the current molecular tests available for $\mathrm{BCa}$ and describe some of the research advances made in biomarker discovery for the non-invasive diagnosis and monitoring of $\mathrm{BCa}$.

\section{Current Molecular Tests for BCa Detection}

A number of commercial molecular tests have been FDAapproved for specific scenarios (Table 1). These tests include the measurement of soluble proteins such as bladder tumor associated antigen (BTA), nuclear matrix protein 22 (NMP22), proteins detected on fixed urothelial cells (ImmunoCyt), and chromosomal aberrations detected by fluorescence in situ hybridization (UroVysion). The reported performance parameters and potential advantages or disadvantages of these tests (based on an assessment of the relevant literature) are discussed below.

\subsection{Voided Urine Cytology}

As it is the gold standard for the detection of malignancy through urinalysis, molecular tests are most often compared to VUC. Actually, VUC is not difficult to outperform given its poor sensitivity, but its established coupling with cystoscopy and its entrenchment as an in-house pathology test means that it remains the go-to test in the majority of health care systems [12]. The lack of sensitivity achieved by VUC is skewed by low-grade and early-stage tumors. These lesions shed relatively few cancer cells into the urine, and as the test relies on microscopic visualization, there is no opportunity to include a signal amplification method to aid the interpretation of minimal samples. However, the detection of high-grade tumors is reported to be over $80 \%$ [4-6]. The VUC test does have a number of advantages, the most obvious of which is the high specificity (i.e., a low rate of false-positive interpretations) $[4,5]$. Furthermore, VUC is a morphological test, so it is not impacted by the presence of blood in a sample (hematuria) or by chemical confounders such as $\mathrm{pH}$ or salt concentrations that can bias or negate biochemical urinary tests. It is a simple test, so it is also not prone to the amplification artifacts or errors inherent to complex molecular techniques. The combination of its high specificity, the inexpensive nature of the equipment required to perform it, the lack of a need for special patient preparation, and its reasonable in-house costs explain why VUC has been the cornerstone of urine-based $\mathrm{BCa}$ detection assays for $>50$ years. Disadvantages of the test include the fact that not every voided urine specimen contains cancer cells. The collection and analysis of three serial first morning specimens for urinary cytology has been shown to reduce the sampling error associated with voided urinary cytology [6], but the feasibility of this approach is impacted by poor patient compliance. Another problem is the subjectivity of the assay. In accordance with accepted

Table 1 FDA-approved urinary assays for bladder cancer

\begin{tabular}{|c|c|c|c|}
\hline Assay & Commercial analyte & $\begin{array}{l}\text { FDA clearance/ } \\
\text { approval }\end{array}$ & Assay type \\
\hline BTA stat & $\begin{array}{l}\text { Bladder tumor associated antigen (human complement factor } \\
\text { H-related protein) }\end{array}$ & $\begin{array}{l}\text { Diagnosis, } \\
\text { monitoring }\end{array}$ & $\begin{array}{l}\text { Colorimetric } \mathrm{Ag}-\mathrm{Ab} \text { reaction } \\
\text { (point of care) }\end{array}$ \\
\hline BTA TRAK & $\begin{array}{l}\text { Bladder tumor associated antigen (human complement factor } \\
\text { H-related protein) }\end{array}$ & $\begin{array}{l}\text { Diagnosis, } \\
\text { monitoring }\end{array}$ & Sandwich immunoassay \\
\hline NMP22 & NUMA1 (nuclear mitotic apparatus protein 1) & $\begin{array}{l}\text { Diagnosis, } \\
\text { monitoring }\end{array}$ & $\begin{array}{l}\text { Colorimetric } \mathrm{Ag}-\mathrm{Ab} \text { reaction } \\
\text { (point of care) }\end{array}$ \\
\hline NMP22 & NUMA1 (nuclear mitotic apparatus protein 1) & Monitoring & Sandwich immunoassay \\
\hline $\begin{array}{l}\text { ImmunoCyt/ } \\
\text { uCyt }+\end{array}$ & High-MW form of glycosylated CEA and MUCIN-like antigens & Monitoring & $\begin{array}{l}\text { Fluorescent antibody } \\
\text { cytology }\end{array}$ \\
\hline UroVysion & $\begin{array}{l}\text { Detection of aneuploidy for chromosomes } 3,7 \text {, and } 17 \text {, and loss of } \\
\text { the } 9 \mathrm{p} 21 \text { locus }\end{array}$ & $\begin{array}{l}\text { Diagnosis, } \\
\text { monitoring }\end{array}$ & $\begin{array}{l}\text { FISH (fluorescence in situ } \\
\text { hybridization) }\end{array}$ \\
\hline
\end{tabular}


nomenclature, VUC results are classified by cytopathologists into four categories: normal, atypical/indeterminate, suspicious, or malignant $[12,13]$. Variability in interpretation and indecisive atypical categorizations can lead to unnecessary invasive and costly follow-up procedures [14].

\subsection{Bladder Tumor Associated Antigen Assays}

Two versions of the BTA test (Polymedco Inc., Cortlandt Manor, NY, USA) are available: BTA stat, an immunochromatographic, qualitative point-of-care assay [15], and BTA TRAK, an ELISA test that measures the human complement factor $\mathrm{H}(\mathrm{cFH})$-related protein in a quantitative fashion [16]. These assays are FDA-approved for the detection and surveillance of $\mathrm{BCa}$ in urine samples [17, 18]. They are simple to perform and interpret, and the versatility of the point-of-care format enables testing at outpatient clinics. For BCa detection, urinary BTA tests have diagnostic sensitivities ranging from 29 to $91 \%$ and specificities ranging from 56 to $86 \%$ [17-19]. While sensitivities can be better for BTA over cytology, the specificity is impacted by other non-cancerous conditions [8].

Many patients visiting the urological clinic present with some level of hematuria, and this is known to interfere with urinalysis tests, potentially causing false-positive or falsenegative diagnostic results [20]. A number of reports have noted that there is often a high correlation between BTA data and hematuria levels [20, 21]. Given the fact that the cFH proteins are serum factors, there is the possibility that BTA tests are monitoring the presence of serum proteins that are introduced through bleeding from the tumor. Strong correlations of BTA levels with hematuria in clinical samples are evident, and urine-spiking models confirm that hematuria can cause false-positive BTA tests at levels that would register as negative or trace hematuria in clinical tests [21-23]. Another concern is the source of the BTA antigen; the large soluble glycoproteins of the cFH family are produced and secreted into the serum by Kupffer cells, hepatocytes, vascular endothelial cells, and platelets [15], and searches of publicly available cancer tissue profiling databases do not support the notion that bladder tumor tissue is a source of $\mathrm{cFH}$.

\subsection{Nuclear Matrix Protein 22 Assays}

Another immunochromographic assay for $\mathrm{BCa}$ detection monitors urinary nuclear matrix protein 22 (NMP22/ NUMA1) [24, 25]. NMP22 is a nuclear mitotic apparatus protein that is responsible for the distribution of chromatin to daughter cells during mitosis [26]. As with the BTA tests, the NMP22 tests also come as a quantitative ELISA or a quantitative point-of-care test known as BladderChek
(Matritech Inc., Newton, MA, USA). The POC test is FDAapproved for initial diagnosis, and both are approved for disease surveillance. The advantages of the POC test include low cost, ease of use, and interpretation without the need for a trained pathologist.

The ELISA test performed reasonably well in early studies [18, 20,24], but has largely been superseded by the POC test, which has been shown to perform at least as well as the original test format with respect to accuracy. In a major study of over 1,300 subjects, the BladderChek NMP22 test achieved a sensitivity of $56 \%$, while cytology achieved only $16 \%$ in the same cohort. The specificity achieved in the study did not equal that of cytology, but was a respectable $86 \%$ [27]. A follow-up study by the same group evaluated the utility of the NMP22 POC test for the surveillance of 668 patients with a history of $\mathrm{BCa}$. The NMP22 test outperformed cytology as an adjunct to cystoscopy, but the sensitivity and specificity of the test alone were 49 and $87 \%$, respectively [28]. Another large cohort study enrolled 1,328 consecutive patients to evaluate the impact of risk factors on the BladderChek NMP22 test. Among the 79 patients with malignancy, the overall positive predictive value (PPV) of the NMP22 test was only $20 \%$, but the PPV was higher in men with a history of smoking and/or those presenting with gross hematuria. The negative predictive value (NPV) was $>95 \%$, except in men with gross hematuria [29]. Most recent cohort studies confirm that the NMP22 test outperforms cytology but not cystoscopy for sensitivity, and specificity is similar to cytology. The test does not reduce the need for cystoscopy $[30,31]$.

The impact of hematuria and infection on NMP22 tests has been noted [24, 31, 32], and experimental models have confirmed the effect of blood by spiking at relatively high levels [22, 33-35]. NMP22 levels can also be elevated in pyuria, urolithiasis, or cystitis, and after instrumentation $[24,32]$. The impact of these conditions on the test may be related to the nature of the NMP22 marker itself. NMP22 is a ubiquitous nuclear protein that is expressed in all tissues with an epithelial component, including the normal urothelial lining of the urinary bladder. In fact, normal tissues often appear to express more NMP22 than malignant tumors [35], so its potential as a biomarker must be related to its release from cells rather than its discrete expression or abundance. Proliferating tumor cells do turn over at a high rate, and many undergo apoptosis, and so the test may reflect that phenomenon, but this makes the test susceptible to any condition that results in a higher rate of turnover than normal urothelia, or any condition that causes cellular damage and release of nuclear contents. Such conditions would include nucleated cells from serum incursion, inflammatory conditions, and damage from instrumentation. 


\subsection{ImmunoCyt Test}

The ImmunoCyt/uCyt+ assay (Scimedx Corp, Denville, $\mathrm{NJ}$, USA) is designed to augment cytology through the detection of cellular biomarkers on cytology slides using a cocktail of fluorescent monoclonal antibodies [36, 37]. The antigens targeted in the test are a high molecular weight form of carcinoembryonic antigen and two bladder tumor cell-associated mucins. This test is performed under microscopy by a trained cytopathologist, and a relatively large number of exfoliated cells are necessary to perform an accurate test. A test is scored as positive when a single red or green cell is observed, but the manufacturer recommends that all positive cells should be correlated to morphology. Conversely, a cytology slide must contain a minimum of 500 cells for a negative score to be valid. Sensitivities of the ImmunoCyt/uCyt+ when combined with cytology are reportedly in the range of $81.0-89.3 \%$, a considerable improvement over cytology alone, but the specificities of the combined assays are less than that achieved by cytology alone, in the range of 61.0-78\% [38-43]. Studies also suggest that ImmunoCyt/uCyt+ has a superior sensitivity to cytology for early pathological stage (Ta-T1) and low-grade tumors, and can significantly improve the detection of carcinoma in situ [39, 40, 42]. As it is a cellular assay, ImmunoCyt/uCyt+ is less impacted by hematuria and inflammatory conditions, but the test is subjective and depends on specimen stability and handling as well as interobserver variation [38]. These limitations restrict the ImmunoCyt test to being recommended as an adjunct to cytology, and it is only approved for the surveillance of patients with a history of $\mathrm{BCa}$.

\subsection{UroVysion FISH Assay}

The UroVysion Bladder Cancer Kit (Abbott Molecular Inc., Des Plaines, IL, USA) is designed to detect aneuploidy for chromosomes 3, 7, and 17 as well as loss of the 9p21 locus via fluorescence in situ hybridization (FISH). It is FDA-approved for analysis of urine specimens from subjects suspected of having BCa. Determination of results is conducted by enumeration of four-color fluorescent signals that are indicative of the copy numbers of chromosomes 3, 7, and 17 and of the p16 gene, through microscopic examination of the nucleus. Results are intended for use in conjunction with (but not in lieu of) current standard diagnostic procedures for the initial diagnosis and surveillance of patients with a history of bladder carcinoma. Analysis requires a fluorescence microscope equipped with appropriate excitation and emission filters. Additional equipment can be used to standardize specimen processing and automate hybridization protocols. Studies that have evaluated the performance of UroVysion have consistently shown that the test can achieve sensitivities in the range of $75 \%$ [44-48], which is an improvement over cytology, and sensitivity increases for higher-grade tumors. Specificity is equal to or lower than that of cytology (65-96\%) [49], but the overall performance of UroVysion is an improvement over cytology alone. As with the ImmunoCyt assay, the test is dependent on the amount of tumor cells available on a cytology slide, so the detection of low-grade and early-stage tumors can be problematic. Also in common with the ImmunoCyt assay, the accuracy of the UroVysion test can be improved by combining the aneuploidy results with cellular morphology. Automated systems that facilitate this show an increase in accuracy, achieving up to $100 \%$ sensitivity [50].

In some UroVysion-based studies, a number of false positives were reported, but follow-up studies have shown that in up to $50 \%$ of such cases, BCa recurrence occurred within months [45]. This suggests that the chromosomal aberrations are evident before malignant lesions are detectable by cystoscopy or any other standard test. Accordingly, the best clinical utility might be in the surveillance of patients who have had BCa previously, where UroVysion would be used to check for aberrations associated with new lesions [51, 52]. The test takes advantage of the high occurrence of specific chromosomal abnormalities in urothelial cancers, but not all BCa lesions harbor these chromosomal aberrations, so the test can only detect a subset of malignancies. The technical demands of the test regarding sample preparation, specialized equipment, and trained personnel requirements as well as a lack of consensus on the definition of abnormality are reasons why UroVysion has not been approved to supersede standard evaluations, including cytology [44], as a standalone test.

\subsection{Summary of Current Tests}

In studies that have compared current tests in the same cohort, there is a trend that shows more robust performance of the cell-based tests (e.g., cytology, UroVysion, and ImmunoCyt). Because these tests are focused on specific cells in the sample, they are less impacted by confounders such as urinary milieu (e.g., gross hematuria, pH, osmolality), or by conditions caused by infection, or by instrument-induced damage associated with sampling [53, 54]. Of the cell-based assays, cytology remains the test with the best specificity, but UroVysion improves upon sensitivity rates $[53,55,56]$. Combining the tests described above does show some improvement over single tests [53, 55, 57]. For example, in a study of over 2,000 cases $(>500$ with $\mathrm{BCa}$ ), the PPVs of the four individual tests-cytology, UroVysion, ImmunoCyt, and NMP22-were improved 
upon when they were used in almost any combination, with the combination including all four tests performing the best [55]. However, although combining tests (i.e., monitoring multiple targets) improves accuracy, proprietary issues mean that this currently requires multiple, distinct tests to be performed, which is not technically or economically feasible.

Another way to combine single tests into more accurate evaluations is to include the test result in a nomogram that can predict the presence of $\mathrm{BCa}[29,58]$, but it is clear that the derivation of multiplex molecular assays will be an important step towards overall accuracy rates that reach those of cystoscopy and cytology.

\section{Investigational Biomarkers for Non-Invasive BCa Detection}

\subsection{Blood-Based Detection of $\mathrm{BCa}$}

There are no blood-based biomarker tests currently in clinical practice for $\mathrm{BCa}$ detection or surveillance. Given the availability of urine for bladder disease monitoring, blood-based analyses have disadvantages that include dilution effects, the complexity of the serum milieu and proteome, and the issue of ascribing a blood-based biomarker to its actual source. The analysis of blood-based biomarkers may have more utility in bladder disease prognosis or informing therapeutic decisions. On the research front, a number of serum biomarkers have been reported to be associated with disease status and/or survival. Serum levels of CYFRA21-1 and soluble E-cadherin were found to be elevated in cases with advanced and highgrade tumors $[9,59]$. Potential prognostic markers include MMP2 and MMP7 [60-62] and endostatin [63]. Serum levels of TGF-B1, uPA, and E-cadherin have been reported to be predictive for lymph node metastasis, disease-free survival, and cancer-specific survival [59, 64, 65].

Another major field of blood-based detection and monitoring for multiple cancers is the isolation of circulating tumor cells (CTCs). Viable tumor-derived epithelial cells are present in the peripheral blood of cancer patients with primary or metastatic disease. Although extremely rare, CTCs represent a potential alternative to invasive biopsies as a source of tumor tissue for the detection, characterization and monitoring of solid tumors. An in-depth discussion of the CTC field is beyond the scope of this review, but a few studies that have investigated this in $\mathrm{BCa}$ are described briefly below.

Given the rarity of CTCs and the difficulty involved in detecting and isolating them, the approach does not offer much for the initial diagnosis of primary disease [66, 67]. There may be more purpose in using this strategy to detect residual disease after surgical intervention and as an aid to adjuvant therapy decisions, or for monitoring subsequent disease recurrence. Early studies used RT-PCR to detect $\mathrm{BCa}$ tumor cells in the patient's peripheral blood [68-70]. Amplification targets that were chosen to identify epithelial cells included CK-20 [68] and uroplakin II [69, 70], survivin [71], and EGFR mRNA [72]. These assays qualitatively determined the presence of CTCs in BCa patients. More recent techniques include immunomagnetic separations and digital imaging. One system that is being used clinically to some extent is the CellSearch assay (Veridex LLC), which employs antibodies targeted at epithelial cell markers (EpCAM and cytokeratins 8, 18, and 19). Using the CellSearch system in a BCa study, CTCs were detected in $44 \%$ of patients with metastatic disease, and the number of detectable cells correlated with the number of metastatic sites [73]. In patients with metastatic cancer, assessment of CTCs may represent an earlier and more reproducible indication of disease status than current imaging modalities. In a clinical follow-up study, the CellSearch system was employed to show that preoperative detection of CTCs, even in patients with non-metastatic disease at the time of surgery, was associated with a worse overall survival compared to CTC-negative patients [74-77]. As technical aspects of CTC detection and analysis improve, the hope is that the characterization of individual cells in the blood will serve as a low-invasive, real-time approach for monitoring molecular changes in cancer occurring in an individual patient, and to track response to therapy. This would enable clinicians to customize treatment strategies as the disease evolves.

\subsection{Multi-Analyte Biomarker Assays}

Given the limitations of the current tests described above, many investigative teams have proposed novel biomarkers for the non-invasive detection of $\mathrm{BCa}$, primarily via urinalysis. Numerous biomarkers with promise have been reported in preliminary studies. Examples include Aurora kinase [78], CEACAM1 [79], telomerase [80], survivin [81], and hyaluronic acid/hyaluronidase [82, 83] at the protein or mRNA level; at the DNA level, mutations in the FGFR3 gene [84, 85] have been proposed to be indicative of BCa. The sensitivities and specificities of these markers are encouraging in specific cohorts (reviewed previously, see [86, 87]), but as with the currently used single-marker clinical tests described above, they are necessarily limited by the fact that not all BCas-or even all of the cases in one specific category of lesions (e.g., stage/grade, growth pattern, etc.) - will harbor any particular molecular change [12]. What is needed are multiplex biomarker assays that can be developed into risk scores and nomograms such that an assay can be applicable over a broad range of disease 
states and be robust against errors. Below we discuss some of the studies that report biomarker panels and tumorassociated signatures of $\mathrm{BCa}$.

\subsection{DNA Markers}

Common cancer-associated genetic aberrations can be detected accurately by monitoring alterations in microsatellite markers and loss of heterogeneity. Many such aberrations have been documented in $\mathrm{BCa}$, and a number of studies have analyzed microsatellite markers in voided urine samples. An early study monitored 17-20 microsatellite biomarkers across multiple chromosomes in serum voided urine sediment [88]. The most frequent mutations found in the urine samples were detected in chromosomes $8 p$ and $9 p$. In a study that monitored nine microsatellite markers in patients with recurrent $\mathrm{BCa}$, a panel of six markers achieved an overall accuracy of $86 \%$ [89]. In a study of over 300 patients, Kompier et al. [90] monitored multiple mutations in five genes, including FGFR3, in bladder tumors. Mutations in individual genes were not overly prevalent (11-63\%), but mutations in one or more target genes were found in $88 \%$ of primary tumors and $88 \%$ of recurrent tumors. Mutation analyses have been applied successfully to voided urine sediments [91, 92], so multiplex assays are entirely feasible. If a diagnostic score could be derived from a mutation screen, it may have utility in diagnosis, and there is also potential for tumorspecific mutations to be useful in follow-up and surveillance for residual or recurrent disease, but these analyses may be more applicable to the stratification of patients for more tailored therapeutic decisions.

The analysis of DNA methylation in cells obtained from voided urine is also an approach that could query multiple gene targets and identify specific patterns associated with BCa. Early studies used methylation-sensitive PCR to identify methylation of the DAPK, RAR $\beta$, E-cadherin, and pl6 genes as being associated with $\mathrm{BCa}$, and the detection of this panel in urine achieved a sensitivity of $91 \%$ and a specificity of $76 \%$ [93]. A similar approach identified the presence of DAPK, BCL2, and TERT gene methylation in $78 \%$ of BCa patients, but they were found to be absent in age-matched controls [94]. Dumiel et al. [95] achieved $87 \%$ sensitivity and $100 \%$ specificity by monitoring hypermethylation of the APC, RASSF1A, and p14 (ARF) genes. A quantitative PCR approach showed that the TWIST1 and NID2 genes are frequently methylated in urine samples collected from BCa patients. The two-gene panel achieved high sensitivity $(90 \%)$ and specificity (93\%) in almost 500 urine samples, significantly outperforming cytology in the same cohort [96]. Through the analysis of nine gene promoters, Hoque et al. [97] found that $69 \%$ of $175 \mathrm{BCa}$ patients had promoter methylation in at least one of four genes (CDKN2A, ARF, MGMT, GSTP1), whereas the control cases had no such methylation detectable. By combining the data from all nine genes, a logistic prediction model was derived that achieved an overall sensitivity of $82 \%$ and specificity of $96 \%$. Importantly, the majority of these studies showed that the methylation pattern was retained between the primary tumor and urine sediment DNA [97]. Numerous other genes have been proposed as valuable methylation biomarkers in recent studies [98-102]. Scher et al. [100] developed a nested methylation-specific PCR assay to detect BCa in small volumes of patient urine. The genes assayed were BCL2, CDKN2A, and NID2. In a pilot study, this assay achieved a sensitivity of $81 \%$ and a specificity of $86 \%$. Costa et al. created a candidate list of methylation markers by assessing cell lines and tissue samples. The methylation status was quantified for two selected genes in 318 clinical samples. PCDH17 and TCF 21 methylation levels in tissue provided a sensitivity rate of $92 \%$ for $\mathrm{BCa}$, but this dropped to $60 \%$ in urine samples [102]. Chung et al. selected ten candidate hypermethylated genes identified in tumor tissue and tested them for detection of $\mathrm{BCa}$ in urine sediments using quantitative methylation-specific RT-PCR (qMSP). Using data from a cohort of $128 \mathrm{BCa}$ patients and 110 age-matched control subjects, a multigene predictive model was derived. A methylation model comprising five target genes (MYO3A, CA10, NKX6-2, DBC1, and SOX11 or PENK) achieved $85 \%$ sensitivity and $95 \%$ specificity for the detection of BCa [101]. These panels of biomarker targets look promising, but a definitive panel needs to be tested in larger cohorts with appropriate controls. The analysis of DNA from urinary sediment is based on PCR technologies, so it has the advantages of being relatively simple, potentially cost-effective, and quantifiable. As it is an amplification technique, it is also possible to achieve data from minimal sample materials.

\subsection{RNA Markers}

Transcribed, non-protein-coding microRNA (miRNA) molecules are key post-transcriptional regulators of gene expression [103]. To date, over 1,500 human miRNAs have been identified and characterized to some extent. Each miRNA controls the expression of multiple genes, so this molecular family may represent an opportunity to identify biomarkers of a higher order. Array-based profiling and deep-sequencing approaches for miRNA analysis are becoming routine technically, and studies targeting miRNAs as potential diagnostic biomarkers are increasing accordingly. Tumor tissue profiling studies have identified the expression of single miRNA transcripts as being associated with primary $\mathrm{BCa}$ or outcome, and some of the candidate biomarkers have been confirmed in urine 
samples [104-109]. Encouragingly, more recent studies have derived signatures or panels of miRNA biomarkers with good diagnostic performance for urinalysis. Hanke et al. [110] examined the expression of 157 miRNAs in exfoliated urothelial cells using quantitative RT-PCR and reported that the ratio of miR-126 to miR-182 achieved $72 \%$ sensitivity and $82 \%$ specificity in a cohort of 47 samples. A quantitative PCR study of a panel of $15 \mathrm{miR}$ NAs in 121 urine samples revealed that a combination of three miRNAs (135b/15b/1224-3p) detected BCa with a high sensitivity $(94.1 \%)$, but the specificity was lower (51\%) [111]. The combination of miR-222 and miR-452 has been reported to be helpful in tumor stratification and for non-invasive diagnosis [108], and the expression of miR-96 and miR-183 has been shown to augment cytology and to correlate with advancing tumor grade and stage [109]. Serum microRNA has also been investigated in $\mathrm{BCa}$ patients. Plasma miRNA was isolated from 20 patients with $\mathrm{BCa} 18$ controls and profiled using arrays. Seventy-nine miRNAs were differentially expressed in patients with or without cancer, and logistic regression modeling was able to predict diagnosis with $89 \%$ accuracy [112]. The miRNAs do hold promise as bladder biomarkers because they are resistant to nuclease degradation and are relatively stable within urine and serum [111, 112].

One of the most promising sources for the derivation of multiplex diagnostic biomarker signatures is the tumor cell transcriptome. Gene expression profiling studies of urological clinical material have focused on the analysis of excised solid tumor tissue. These studies have identified gene signatures that are associated with tumor stage [113, 114], disease recurrence and outcome prediction [113115], and subtype classification [114]. The fact that followup studies have validated some of the biomarkers in independent tissue collections shows the potential utility of microarray profiling of solid tissue source materials [116, 117]; however, the molecular analysis of solid tissue is most applicable to the development of assays that will aid the histological evaluation of biopsy or excised tumor material. Normal tissue is not available for comparison for obvious reasons.

Analysis of naturally shed urothelia has several advantages (described above for existing and investigational assays) - stable material source, low impact of urinary milieu, comparison with morphological and other cellular markers, and availability of samples from the complete range of disease conditions and healthy controls. Through PCR amplification, the analysis can be performed on the often minimal cellular material obtained from naturally voided urine, and the detection methods are accurate, quantitative, and economical. A number of groups have profiled excised tissue, and some of the mRNA targets identified in such studies have been monitored in urine as potential non-invasive biomarkers. Holyoake et al. [118] also published a study that used molecular profiling of solid tissues to identify genes that were overexpressed in tumor stages $\mathrm{Ta}, \mathrm{T} 1$, or $>\mathrm{T} 1$, relative to non-tumor epithelial tissues and inflammatory cells. Using this strategy, $C D C 2$, $M D K, I G F B P 5$, and HOXA13 were selected for the development of a quantitative RT-PCR urine assay for TCC detection and disease risk stratification of patients. RNA for the assay was extracted from voided urine samples, but it is not clear whether this extraction would have included urothelial cells or only soluble urinary RNA. The measurement of the combination of mRNA markers detected $\mathrm{BCa}$ at a sensitivity of $85 \%$ and a specificity of $80 \%$ across all stages, with the best performance obtained with stages $>\mathrm{T} 1$ and tumors $>1 \mathrm{~cm}$ in diameter [118]. A recent study by the same team compared the performances of assays derived from this biomarker panel and currently under commercial development (uRNA Assay, Pacific Edge Ltd., Dunedin, New Zealand). In a cohort of 485 patients presenting with hematuria, the uRNA test achieved a higher sensitivity $(62 \%)$ than NMP22 (ELISA and BladderChek) and cytology at a pre-specified specificity of $85 \%$, and a modification of the assay derived from the 485-cohort data detected $82 \%$ of BCa cases [119]. Hanke et al. analyzed the expression of a selected panel of mRNAs as biomarkers of $\mathrm{BCa}$ in whole urine, cell pellets, and clarified urine. In a cohort of 98 subjects, they found that the ratio of v-ets erythroblastosis virus E26 oncogene homolog 2 (ETS2) to urokinase plasminogen activator $(P L A U)$ in whole urine facilitated the detection of $\mathrm{BCa}$ with a sensitivity of $75 \%$ at $100 \%$ specificity [120]. Other mRNA-based diagnostic urinalyses have targeted BIRC5 (survivin), HYAL1, KRT20, and MUC7 [121-123]. These targets performed similarly at sensitivities between 62 and $90 \%$, and confirmed that combinations of 2-3 mRNA markers perform better than single-target assays.

The feasibility of transcriptome profiling of the exfoliated urothelia present in urine has recently been shown $[124,125]$, and the approach has been used to identify tumor-associated profiles with high diagnostic accuracy $[125,126]$. In one study, the genome-wide mRNA profiles of over 90 urothelial samples were subjected to advanced feature selection algorithms [127-129] to reveal an optimal gene signature for $\mathrm{BCa}$ prediction. A 14-gene signature was able to detect $\mathrm{BCa}$ with $100 \%$ specificity at $90 \%$ sensitivity in an independent cohort of 81 cases using quantitative RT-PCR [124, 126]. In comparison, cytological evaluation of this cohort diagnosed only $35 \%$ of tumor cases correctly. In a study utilizing a similar strategy, a panel of 384 genes that were identified in tissue-based analyses was subsequently tested in urothelial samples using quantitative RT-PCR [125]. Analyses identified a 12-gene signature that achieved high accuracy (89\% 
sensitivity and $95 \%$ specificity) in identifying BCa cases in a cohort of 211 subjects. Despite significant differences between the studies with respect to the biomarker discovery phase, both groups were able to derive molecular signatures that could accurately classify BCa samples. This demonstrates that a multiplex quantitative RT-PCR test of voided urine samples holds promise as a non-invasive urine-based assay in the evaluation of patients being investigated for $\mathrm{BCa}$. Although a quantitative RT-PCR test has some upfront processing requirements, it has the advantage of being developed into an assay that can be automated and highly standardized for consistency between laboratory sites.

One of the major advantages of multiple biomarker assays is that the results can be input into algorithms that can provide a continuous score for predicting disease status or prognosis. This provides much more useful information than cut-off data, and is being used in clinical tests in the breast cancer prognosis field [130]. Furthermore, algorithms that incorporate clinical data and molecular risk scores into a nomogram can give the physician the most valuable guidance regarding patient management decisions $[131,132]$.

\subsection{Protein Biomarkers}

Numerous investigations have tested the diagnostic utility of various proteins that have previously been associated with bladder disease status. The majority of studies have tested single biomarkers in diverse cohorts, or combined novel and current tests in combination [133], but increasingly multiplex combinations are being evaluated. A study by Abogunrin et al. evaluated 23 previously reported protein biomarkers for bladder disease in urine from a cohort of 80 patients with $\mathrm{BCa}$ and 77 controls. Univariate analysis revealed that nine biomarkers were significantly differentially expressed with respect to cancer burden. Multivariate algorithms that combined demographic information (age and smoking history) with molecular data significantly improved performance compared to demographic information alone. A combination of NMP22, BTA, serum CEA, EGF, and thrombomodulin enabled sensitivities of up to $91 \%$, and specificities of up to $80 \%$ [132]. Based on the fact that cancer often involves inflammatory processes, Margel et al. [134] monitored a panel of immune modulators in urine to investigate biomarker potential. The panel included 15 heat shock proteins and cytokines, monitored by commercial ELISA assays. The combined urinary concentrations of HSP60 and IL-13 significantly improved the performance over any single factor.

The discovery of novel protein biomarker panels has surged recently due to advances in high-throughput proteomic technologies. The appropriate use of these approaches has the potential to provide highly efficient biomarkers for $\mathrm{BCa}$ detection and monitoring. Proteinbased biomarkers have several advantages over nucleic acid targets. Only proteomic profiling enables the evaluation of global changes in gene expression that result from both transcriptional, translation, and post-translation modifications. Although genomics may be more amenable to comprehensive surveys, phenotypic changes can only manifest themselves through altered protein expression, so the identification of protein factors involved in bladder disease can best inform us of tumor biology. Beyond their diagnostic and prognostic value, protein biomarkers provide potential therapeutic targets and represent markers of disease progression, treatment response, and other clinical utilities.

Proteome profiling studies have tended to identify factors that can classify tumors or predict patient outcome or disease recurrence, but biomarkers identified in solid tissue may be subsequently translated into a serum or urinary test, and some have shown promise as urinary diagnostic markers. Examples from proteomic analyses include psoriasin for squamous cell carcinoma [135], TACSTD2 [136], and cystatin B [137], and panels for serum-based diagnosis [138], but direct proteomic analysis of the urine is more likely to reveal promising non-invasive diagnostic biomarkers. Early urinary profiling studies used gel-based technologies to define the urinary proteome and to begin to identify proteins associated with BCa [139-142], but advances in MS technology have been rapidly applied to the profiling of bladder tissues, serum, and urine. Vlahou et al. [143] used SELDI-TOF to compare the proteomic profiles of urine samples from healthy controls and patients with transitional cell carcinoma of the bladder. Multiple protein changes were reproducibly detected in the cancer group, including five potential novel biomarkers and several protein clusters. One of the biomarkers, alpha-defensin, was subsequently shown to be present in bladder tumor cells. The combination of the biomarkers and protein clusters significantly improved the accuracy of patient classification. In a separate cross-validation study by the same authors [144], alpha-defensin monitoring was used to detect $\mathrm{BCa}$ with better sensitivity and specificity than commercial tests. Theodorescu et al. [145] used capillary electrophoresis (CE)-mass spectrometry to identify urinary biomarkers for $\mathrm{BCa}$ in a training set composed of 46 patients with urothelial carcinoma and 33 healthy volunteers. These were further refined using CE-MS spectra of another cohort of urine samples from healthy volunteers and patients with malignant and nonmalignant genitourinary diseases. Using this two-step approach, a diagnostic biomarker signature of 22 urinary peptides was established. In a validation study, this signature enabled the correct 
classification of all urothelial carcinoma patients in a test set containing 31 urothelial carcinoma patients and 138 nonmalignant genitourinary disease patients [145].

Another study used an isobaric tag for relative and absolute quantitation (iTRAQ) technique to discover proteins that were differentially expressed between pooled urine samples and non-tumor controls. This strategy identified 55 candidate biomarker proteins. Orthogonal techniques confirmed that the level of apolipoprotein A-I (APOA1) was significantly elevated in urine samples from BCa patients. Using a commercial ELISA assay, APOA1 was confirmed to have high diagnostic potential in an extended sample set [146]. Using a glycoprotein enrichment strategy to profile urine samples from 100 subjects (54 with cancer), Yang et al. [147] identified a panel of glycoproteins associated with BCa. The most discriminatory protein in that study was alpha-1-antitrypsin (A1AT), also known as SERPINA1. In an independent validation cohort of 70 subjects, A1AT measurement by ELISA achieved a sensitivity of $74 \%$ and a specificity of $80 \%$ [147]. Through integration of proteomic and genomic urine sample profiling data [124, 126, 147, 148], we identified panels of promising biomarkers for inclusion in diagnostic urinalysis assays. Combinations of 2-3 biomarkers were analyzed by ELISA in a series of studies [149-151], and multivariate analysis identified an eight-protein biomarker panel that achieved $92 \%$ sensitivity and $97 \%$ specificity in cohorts of 64 patients with BCa and 63 controls [152]. The performance was far better than current urinalysis tests in the same cohort. Validation of these multiplex biomarker panels in larger, more diverse cohorts is underway. BCa biomarker panels discovered by proteomic profiling have also been derived from serum samples. Schwamborn and colleagues searched for discriminating protein patterns in serum using magnetic bead-based separation followed by MALDI-TOF MS. Multidimensional analyses of serum samples from 105 patients with $\mathrm{BCa}, 98$ healthy controls, and 45 prostate cancer patients generated algorithms capable of distinguishing between cancer patients and healthy individuals. The best algorithm achieved $96 \%$ sensitivity and $86 \%$ specificity [138]. The studies described above show the power of MS-based urinary analysis for the discovery of biomarkers. The latest proteomic technological developments, such as arrays for phosphoproteins, glycoproteins, or phospholipoproteins, can reduce the sample complexity that plagues the proteomic analysis of biological fluids. As these techniques are applied to BCa samples, there will likely be further advances in urinary biomarker discovery.

\subsection{Metabolomic Biomarkers}

The most recent developments in biological fluid analyses have come in the field of metabolomics. The application of urine-based metabolomics using high-pressure liquid chromatography (HPLC) or nuclear magnetic resonance (NMR) with multivariate analysis can identify specific metabolites or profiles that can aid cancer diagnosis [153]. To date, only a few studies have investigated differential urine metabolite profiles associated with BCa. Using HPLC, Issaq et al. [154] profiled urine samples from 41 patients with $\mathrm{BCa}$ and 48 healthy controls. Statistical analyses allowed at least 40 of the $41 \mathrm{BCa}$ cases to be predicted correctly, but the specific metabolites identified in that study have not been confirmed elsewhere. In a similar study format, Pasikanti et al. [155] identified a 15-marker metabolite model that achieved a $100 \%$ detection rate for $\mathrm{BCa}$ in 24 patients. Another study of 58 clinical specimens identified 35 metabolites associated with BCa. The metabolic signature distinguished both normal and benign bladder from $\mathrm{BCa}$, and even showed promise in distinguishing tumor stages [156]. There was no overlap between the profiles identified in the studies, and it remains to be seen whether these preliminary urinary studies can be built upon. A recent study used NMR-based metabolomics to investigate differences in serum metabolic profiles associated with $\mathrm{BCa}$. In a study of 67 patients and 25 healthy controls, serum sample profiles from $\mathrm{BCa}$ patients suggested perturbed metabolic pathways of aromatic amino acids, glycolysis and the citrate cycle, and lipogenesis [157].

Changes at the metabolite level may be detectable in biological fluids before the appearance of clinical symptoms, making them potentially useful early detection biomarkers, and metabolic profiling can provide insights into bioprocesses perturbed during tumor development and progression; however, there are major problems with urinary metabolomic profiling. The analytes are small metabolites that are not always filtered by the kidney, so confounding factors such as polypharmacy or even recent dietary intake can create large variations between individuals, so such studies require large cohorts and standardization of sample collection and processing.

\section{Conclusions}

Detecting BCa using diagnostic markers remains a challenge. The inadequate power of single markers may partly explain this. The concept that the presence or absence of one molecular marker will aid clinical evaluation has not proved to be the case. This makes sense when one considers the complex interactions between various molecules within a single pathway, the cross-talk between molecular pathways, and the oligoclonality of many tumors. Advances in molecular techniques, especially profiling approaches, have enabled investigators to derive a new generation of compound molecular diagnostic signatures that may 
provide assays with the desired clinical utility. Technology is also extending the range of molecular classes that may serve as potential biomarkers. Potential biomarkers that can provide valuable information and are amenable to urinalysis include proteins, mRNA and microRNA, DNA markers that include mutated sequence or epigenetic information, and metabolite concentrations. It may well be that the most efficient diagnostic signatures are multifaceted, including a mix of molecular classes, and instead of trying to replace existing clinical criteria in patient evaluation, combining both clinical and biomarker information in nomograms is a promising strategy.

Multiplex marker systems for $\mathrm{BCa}$ diagnosis are still at an early stage compared with the FDA-approved markers. Signatures and panels of markers have been derived and tested on varied cohorts, and require further validation in independent studies. Validation studies that incorporate more diverse cohorts may require the adjustment of combinatorial assay components to match performance data derived from the initial discovery studies, but that flexibility is one of the advantages of multiplex marker assays, and the hope is that they will provide robust tests that can be informative across the broad range of clinical presentation. If fully tested and optimized, multiplex diagnostic assays may enter the clinical setting to augment, or eventually even replace, cystoscopy and/or cytology for diagnosis and recurrence monitoring. Such assays may also guide other aspects of patient management, including therapeutic intervention decisions and monitoring of response to treatment.

Acknowledgements The authors are supported in part by research grants from the National Cancer Institute (grant no. RO1 CA116161 [SG]) and the Florida Department of Health James and Esther King Biomedical Program (Team Science Award no. 10KT-01 [CJR] and TTF Award no. IKF06 [SG]). Authors SG and CJR are co-founders and officers of Nonagen Bioscience Corporation. Author VU has no conflict of interest to declare.

Open Access This article is distributed under the terms of the Creative Commons Attribution Noncommercial License which permits any noncommercial use, distribution, and reproduction in any medium, provided the original author(s) and the source are credited.

\section{References}

1. Siegel R, Naishadham D, Jemal A. Cancer statistics, 2012. CA Cancer J Clin. 2012;62(1):10-29.

2. Kaufman DS, Shipley WU, Feldman AS. Bladder cancer. Lancet. 2009;374(9685):239-49.

3. Millan-Rodriguez F, Chechile-Toniolo G, Salvador-Bayarri J, Palou J, Algaba F, Vicente-Rodriguez J. Primary superficial bladder cancer risk groups according to progression, mortality and recurrence. J Urol. 2000;164(3 Pt 1):680-4.
4. Trivedi D, Messing EM. Commentary: the role of cytologic analysis of voided urine in the work-up of asymptomatic microhematuria. BMC Urol. 2009;9:13.

5. Tetu B. Diagnosis of urothelial carcinoma from urine. Mod Pathol. 2009;22(Suppl 2):S53-9.

6. Nakamura K, Kasraeian A, Iczkowski KA, Chang M, Pendleton $\mathrm{J}$, Anai S, et al. Utility of serial urinary cytology in the initial evaluation of the patient with microscopic hematuria. BMC Urol. 2009;9:12.

7. Kumar A, Kumar R, Gupta NP. Comparison of NMP22 BladderChek test and urine cytology for the detection of recurrent bladder cancer. Jpn J Clin Oncol. 2006;36(3):172-5.

8. Raitanen MP, Aine R, Rintala E, Kallio J, Rajala P, Juusela H, et al. Differences between local and review urinary cytology in diagnosis of bladder cancer. An interobserver multicenter analysis. Eur Urol. 2002;41(3):284-9.

9. Washino S, Hirai M, Matsuzaki A, Kobayashi Y. Clinical usefulness of CEA, CA19-9, and CYFRA 21-1 as tumor markers for urothelial bladder carcinoma. Urol Int. 2011;87(4):420-8.

10. Gakis G, Todenhofer T, Stenzl A. The prognostic value of hematological and systemic inflammatory disorders in invasive bladder cancer. Curr Opin Urol. 2011;21(5):428-33.

11. Schwamborn K, Gaisa NT, Henkel C. Tissue and serum proteomic profiling for diagnostic and prognostic bladder cancer biomarkers. Expert Rev Proteomics. 2010;7(6):897-906.

12. Kamat AM, Hegarty PK, Gee JR, Clark PE, Svatek RS, Hegarty $\mathrm{N}$, et al. ICUD-EAU international consultation on bladder cancer 2012: screening, diagnosis, and molecular markers. Eur Urol. 2012;4:S0302-2838.

13. Murphy WM. Current status of urinary cytology in the evaluation of bladder neoplasms. Hum Pathol. 1990;21(9):886-96.

14. Karakiewicz PI, Benayoun S, Zippe C, Ludecke G, Boman H, Sanchez-Carbayo M, et al. Institutional variability in the accuracy of urinary cytology for predicting recurrence of transitional cell carcinoma of the bladder. BJU Int. 2006;97(5):997-1001.

15. Gutiérrez Baños JL, del Henar Rebollo Rodrigo M, Antolín Juárez FM, García BM. Usefulness of the BTA STAT test for the diagnosis of bladder cancer. Urology. 2001;57(4):685-9.

16. van Rhijn BW, van der Poel HG, van der Kwast TH. Urine markers for bladder cancer surveillance: a systematic review. Eur Urol. 2005;47(6):736-48.

17. Thomas L, Leyh H, Marberger M, Bombardieri E, Bassi P, Pagano F, et al. Multicenter trial of the quantitative BTA TRAK assay in the detection of bladder cancer. Clin Chem. 1999;45(4):472-7.

18. Mahnert B, Tauber S, Kriegmair M, Nagel D, Holdenrieder S, Hofmann K, et al. Measurements of complement factor $\mathrm{H}$-related protein (BTA-TRAK assay) and nuclear matrix protein (NMP22 assay) - useful diagnostic tools in the diagnosis of urinary bladder cancer? Clin Chem Lab Med. 2003; 41(1):104-10.

19. Ellis WJ, Blumenstein BA, Ishak LM, Enfield DL. Clinical evaluation of the BTA TRAK assay and comparison to voided urine cytology and the Bard BTA test in patients with recurrent bladder tumors. The Multi Center Study Group. Urology. 1997;50(6):882-7.

20. Ramakumar S, Bhuiyan J, Besse JA, Roberts SG, Wollan PC, Blute ML, et al. Comparison of screening methods in the detection of bladder cancer. J Urol. 1999;161(2):388-94.

21. Oge O, Kozaci D, Gemalmaz H. The BTA stat test is nonspecific for hematuria: an experimental hematuria model. $\mathrm{J}$ Urol. 2002;167(3):1318-9 (discussion 1319-20).

22. Hennenlotter J, Huber S, Todenhofer T, Kuehs U, Schilling D, Aufderklamm S, et al. Point-of-care tests for bladder cancer: the influencing role of hematuria. Adv Urol. 2011;2011:937561. 
23. Miyake M, Goodison S, Rizwani W, Ross S, Bart Grossman H, Rosser CJ. Urinary BTA: indicator of bladder cancer or of hematuria. World J Urol. 2012;30:869-73.

24. Ponsky LE, Sharma S, Pandrangi L, Kedia S, Nelson D, Agarwal A, et al. Screening and monitoring for bladder cancer: refining the use of NMP22. J Urol. 2001;166(1):75-8.

25. Chang YH, Wu CH, Lee YL, Huang PH, Kao YL, Shiau MY. Evaluation of nuclear matrix protein-22 as a clinical diagnostic marker for bladder cancer. Urology. 2004;64(4):687-92.

26. Berezney R, Coffey DS. Identification of a nuclear protein matrix. Biochem Biophys Res Commun. 1974;60(4):1410-7.

27. Grossman HB, Messing E, Soloway M, Tomera K, Katz G, Berger $\mathrm{Y}$, et al. Detection of bladder cancer using a point-ofcare proteomic assay. JAMA. 2005;293(7):810-6.

28. Grossman HB, Soloway M, Messing E, Katz G, Stein B, Kassabian V, et al. Surveillance for recurrent bladder cancer using a point-of-care proteomic assay. JAMA. 2006; 295(3):299-305.

29. Lotan Y, Capitanio U, Shariat SF, Hutterer GC, Karakiewicz PI. Impact of clinical factors, including a point-of-care nuclear matrix protein-22 assay and cytology, on bladder cancer detection. BJU Int. 2009;103(10):1368-74.

30. Schlake A, Crispen PL, Cap AP, Atkinson T, Davenport D, Preston DM. NMP-22, urinary cytology, and cystoscopy: a 1 year comparison study. Can J Urol. 2012;19(4):6345-50.

31. Huber S, Schwentner C, Taeger D, Pesch B, Nasterlack M, Leng $\mathrm{G}$, et al. Nuclear matrix protein-22: a prospective evaluation in a population at risk for bladder cancer. Results from the UroScreen study. BJU Int. 2012;110(5):699-708.

32. Sharma S, Zippe CD, Pandrangi L, Nelson D, Agarwal A. Exclusion criteria enhance the specificity and positive predictive value of NMP22 and BTA stat. J Urol. 1999;162(1):53-7.

33. Yokoyama T, Sekigawa R, Hayashi T, Horita S, Kanamuro T, Nonami Y, et al. The clinical efficacy of Bladder Chek NMP22 in urothelial cancer. Rinsho Byori. 2004;52(3):199-203.

34. Atsu N, Ekici S, Oge OO, Ergen A, Hascelik G, Ozen H. Falsepositive results of the NMP22 test due to hematuria. J Urol. 2002;167(2 Pt 1):555-8.

35. Miyake M, Goodison S, Giacoia EG, Rizwani W, Ross S, Rosser CJ. Influencing factors on the NMP-22 urine assay: an experimental model. BMC Urol. 2012;12:23.

36. Greene KL, Berry A, Konety BR. Diagnostic utility of the ImmunoCyt/uCyt+ test in bladder cancer. Rev Urol. 2006; 8(4):190-7.

37. Li HX, Li M, Li CL, Ma JH, Wang MR, Rao J, et al. ImmunoCyt and cytokeratin 20 immunocytochemistry as adjunct markers for urine cytologic detection of bladder cancer: a prospective study. Anal Quant Cytol Histol. 2010;32(1):45-52.

38. Hautmann S, Toma M, Lorenzo Gomez MF, Friedrich MG, Jaekel T, Michl U, et al. ImmunoCyt and the HA-HAase urine tests for the detection of bladder cancer: a side-by-side comparison. Eur Urol. 2004;46(4):466-71.

39. Lodde M, Mian C, Comploj E, Palermo S, Longhi E, Marberger $\mathrm{M}$, et al. uCyt+ test: alternative to cystoscopy for less-invasive follow-up of patients with low risk of urothelial carcinoma. Urology. 2006;67(5):950-4.

40. Messing EM, Teot L, Korman H, Underhill E, Barker E, Stork B, et al. Performance of urine test in patients monitored for recurrence of bladder cancer: a multicenter study in the United States. J Urol. 2005;174(4 Pt 1):1238-41.

41. Mian C, Maier K, Comploj E, Lodde M, Berner L, Lusuardi L, et al. uCyt+/ImmunoCyt in the detection of recurrent urothelial carcinoma: an update on 1991 analyses. Cancer. 2006; 108(1):60-5.
42. Tetu B, Tiguert R, Harel F, Fradet Y. ImmunoCyt/uCyt+ improves the sensitivity of urine cytology in patients followed for urothelial carcinoma. Mod Pathol. 2005;18(1):83-9.

43. Toma MI, Friedrich MG, Hautmann SH, Jakel KT, Erbersdobler A, Hellstern A, et al. Comparison of the ImmunoCyt test and urinary cytology with other urine tests in the detection and surveillance of bladder cancer. World J Urol. 2004;22(2):145-9.

44. Caraway NP, Khanna A, Fernandez RL, Payne L, Bassett RL Jr, Zhang HZ, et al. Fluorescence in situ hybridization for detecting urothelial carcinoma: a clinicopathologic study. Cancer Cytopathol. 2010;118(5):259-68.

45. Halling KC, King W, Sokolova IA, Meyer RG, Burkhardt HM, Halling AC, et al. A comparison of cytology and fluorescence in situ hybridization for the detection of urothelial carcinoma. J Urol. 2000;164(5):1768-75.

46. Sarosdy MF, Kahn PR, Ziffer MD, Love WR, Barkin J, Abara $\mathrm{EO}$, et al. Use of a multitarget fluorescence in situ hybridization assay to diagnose bladder cancer in patients with hematuria. J Urol. 2006;176(1):44-7.

47. Laudadio J, Keane TE, Reeves HM, Savage SJ, Hoda RS, Lage $\mathrm{JM}$, et al. Fluorescence in situ hybridization for detecting transitional cell carcinoma: implications for clinical practice. BJU Int. 2005;96(9):1280-5.

48. Halling KC, King W, Sokolova IA, Karnes RJ, Meyer RG, Powell EL, et al. A comparison of BTA stat, hemoglobin dipstick, telomerase and Vysis UroVysion assays for the detection of urothelial carcinoma in urine. J Urol. 2002;167(5):2001-6.

49. Riesz P, Lotz G, Paska C, Szendroi A, Majoros A, Nemeth Z, et al. Detection of bladder cancer from the urine using fluorescence in situ hybridization technique. Pathol Oncol Res. 2007;13(3):187-94.

50. Daniely M, Rona R, Kaplan T, Olsfanger S, Elboim L, Freiberger A, et al. Combined morphologic and fluorescence in situ hybridization analysis of voided urine samples for the detection and follow-up of bladder cancer in patients with benign urine cytology. Cancer. 2007;111(6):517-24.

51. Moonen PM, Merkx GF, Peelen P, Karthaus HF, Smeets DF, Witjes JA. UroVysion compared with cytology and quantitative cytology in the surveillance of non-muscle-invasive bladder cancer. Eur Urol. 2007;51(5):1275-80 (discussion 1280).

52. Fritsche HM, Burger M, Dietmaier W, Denzinger S, Bach E, Otto W, et al. Multicolor FISH (UroVysion) facilitates followup of patients with high-grade urothelial carcinoma of the bladder. Am J Clin Pathol. 2010;134(4):597-603.

53. Horstmann M, Patschan O, Hennenlotter J, Senger E, Feil G, Stenzl A. Combinations of urine-based tumour markers in bladder cancer surveillance. Scand J Urol Nephrol. 2009; 43(6):461-6.

54. Todenhofer T, Hennenlotter J, Witstruk M, Gakis G, Aufderklamm S, Kuehs U, et al. Influence of renal excretory function on the performance of urine based markers to detect bladder cancer. J Urol. 2012;187(1):68-73.

55. Todenhofer T, Hennenlotter J, Aufderklamm S, Kuhs U, Gakis $\mathrm{G}$, Germann $\mathrm{M}$, et al. Individual risk assessment in bladder cancer patients based on a multi-marker panel. J Cancer Res Clin Oncol. 2012;139(1):49-56.

56. Friedrich MG, Toma MI, Hellstern A, Pantel K, Weisenberger DJ, Noldus J, et al. Comparison of multitarget fluorescence in situ hybridization in urine with other noninvasive tests for detecting bladder cancer. BJU Int. 2003;92(9):911-4.

57. Bravaccini S, Casadio V, Gunelli R, Bucchi L, Zoli W, Amadori D, et al. Combining cytology, TRAP assay, and FISH analysis for the detection of bladder cancer in symptomatic patients. Ann Oncol. 2011;22(10):2294-8. 
58. Nguyen CT, Stephenson AJ, Kattan MW. Are nomograms needed in the management of bladder cancer? Urol Oncol. 2010;28(1):102-7.

59. Matsumoto K, Shariat SF, Casella R, Wheeler TM, Slawin KM, Lerner SP. Preoperative plasma soluble E-cadherin predicts metastases to lymph nodes and prognosis in patients undergoing radical cystectomy. J Urol. 2003;170(6 Pt 1):2248-52.

60. Vasala K, Kuvaja P, Turpeenniemi-Hujanen T. Low circulating levels of ProMMP-2 are associated with adverse prognosis in bladder cancer. Tumour Biol. 2008;29(5):279-86.

61. Svatek RS, Shah JB, Xing J, Chang D, Lin J, McConkey DJ, et al. A multiplexed, particle-based flow cytometric assay identified plasma matrix metalloproteinase-7 to be associated with cancer-related death among patients with bladder cancer. Cancer. 2010;116(19):4513-9.

62. Szarvas T, Becker M, vom Dorp F, Gethmann C, Totsch M, Bankfalvi A, et al. Matrix metalloproteinase-7 as a marker of metastasis and predictor of poor survival in bladder cancer. Cancer Sci. 2010;101(5):1300-8.

63. Szarvas T, Laszlo V, Vom Dorp F, Reis H, Szendroi A, Romics I, et al. Serum endostatin levels correlate with enhanced extracellular matrix degradation and poor patients' prognosis in bladder cancer. Int J Cancer. 2012;130(12):2922-9.

64. Shariat SF, Kim JH, Andrews B, Kattan MW, Wheeler TM, Kim IY, et al. Preoperative plasma levels of transforming growth factor beta(1) strongly predict clinical outcome in patients with bladder carcinoma. Cancer. 2001;92(12):2985-92.

65. Shariat SF, Monoski MA, Andrews B, Wheeler TM, Lerner SP, Slawin KM. Association of plasma urokinase-type plasminogen activator and its receptor with clinical outcome in patients undergoing radical cystectomy for transitional cell carcinoma of the bladder. Urology. 2003;61(5):1053-8.

66. Msaouel P, Koutsilieris M. Diagnostic value of circulating tumor cell detection in bladder and urothelial cancer: systematic review and meta-analysis. BMC Cancer. 2011;11:336.

67. Small AC, Gong Y, Oh WK, Hall SJ, van Rijn CJ, Galsky MD. The emerging role of circulating tumor cell detection in genitourinary cancer. J Urol. 2012;188(1):21-6.

68. Fujii Y, Kageyama Y, Kawakami S, Kihara K, Oshima H. Detection of disseminated urothelial cancer cells in peripheral venous blood by a cytokeratin 20 -specific nested reverse transcriptase-polymerase chain reaction. Jpn J Cancer Res. 1999;90(7):753-7.

69. Li SM, Zhang ZT, Chan S, McLenan O, Dixon C, Taneja S, et al. Detection of circulating uroplakin-positive cells in patients with transitional cell carcinoma of the bladder. J Urol. 1999;162(3 Pt 1):931-5.

70. Lu JJ, Kakehi Y, Takahashi T, Wu XX, Yuasa T, Yoshiki T, et al. Detection of circulating cancer cells by reverse transcription-polymerase chain reaction for uroplakin II in peripheral blood of patients with urothelial cancer. Clin Cancer Res. 2000;6(8):3166-71.

71. Gradilone A, Petracca A, Nicolazzo C, Gianni W, Cortesi E, Naso G, et al. Prognostic significance of survivin-expressing circulating tumour cells in T1G3 bladder cancer. BJU Int. 2010;106(5):710-5.

72. Gazzaniga P, Gandini O, Giuliani L, Magnanti M, Gradilone A, Silvestri I, et al. Detection of epidermal growth factor receptor mRNA in peripheral blood: a new marker of circulating neoplastic cells in bladder cancer patients. Clin Cancer Res. 2001;7(3):577-83.

73. Gallagher DJ, Milowsky MI, Ishill N, Trout A, Boyle MG, Riches J, et al. Detection of circulating tumor cells in patients with urothelial cancer. Ann Oncol. 2009;20(2):305-8.

74. Rink M, Chun FK, Minner S, Friedrich M, Mauermann O, Heinzer $\mathrm{H}$, et al. Detection of circulating tumour cells in peripheral blood of patients with advanced non-metastatic bladder cancer. BJU Int. 2011;107(10):1668-75.

75. Rink M, Chun FK, Dahlem R, Soave A, Minner S, Hansen J, et al. Prognostic role and HER2 expression of circulating tumor cells in peripheral blood of patients prior to radical cystectomy: a prospective study. Eur Urol. 2012;61(4):810-7.

76. Gazzaniga P, Gradilone A, de Berardinis E, Busetto GM, Raimondi C, Gandini O, et al. Prognostic value of circulating tumor cells in nonmuscle invasive bladder cancer: a cell search analysis. Ann Oncol. 2012;23(9):2352-6.

77. Flaig TW, Wilson S, van Bokhoven A, Varella-Garcia M, Wolfe $\mathrm{P}$, Maroni $\mathrm{P}$, et al. Detection of circulating tumor cells in metastatic and clinically localized urothelial carcinoma. Urology. 2011;78(4):863-7.

78. Park HS, Park WS, Bondaruk J, Tanaka N, Katayama H, Lee S, et al. Quantitation of Aurora kinase A gene copy number in urine sediments and bladder cancer detection. J Natl Cancer Inst. 2008;100(19):1401-11.

79. Tilki D, Singer BB, Shariat SF, Behrend A, Fernando M, Irmak $S$, et al. CEACAM1: a novel urinary marker for bladder cancer detection. Eur Urol. 2010;57(4):648-54.

80. Sanchini MA, Gunelli R, Nanni O, Bravaccini S, Fabbri C, Sermasi A, et al. Relevance of urine telomerase in the diagnosis of bladder cancer. JAMA. 2005;294(16):2052-6.

81. Weikert S, Christoph F, Schrader M, Krause H, Miller K, Muller M. Quantitative analysis of survivin mRNA expression in urine and tumor tissue of bladder cancer patients and its potential relevance for disease detection and prognosis. Int $\mathrm{J}$ Cancer. 2005;116(1):100-4.

82. Lokeshwar VB, Obek C, Soloway MS, Block NL. Tumorassociated hyaluronic acid: a new sensitive and specific urine marker for bladder cancer. Cancer Res. 1997;57(4):773-7.

83. Lokeshwar VB, Obek C, Pham HT, Wei D, Young MJ, Duncan $\mathrm{RC}$, et al. Urinary hyaluronic acid and hyaluronidase: markers for bladder cancer detection and evaluation of grade. J Urol. 2000;163(1):348-56.

84. Zuiverloon TC, Tjin SS, Busstra M, Bangma CH, Boeve ER, Zwarthoff EC. Optimization of nonmuscle invasive bladder cancer recurrence detection using a urine based FGFR3 mutation assay. J Urol. 2011;186(2):707-12.

85. van Oers JM, Lurkin I, van Exsel AJ, Nijsen Y, van Rhijn BW, van der Aa MN, et al. A simple and fast method for the simultaneous detection of nine fibroblast growth factor receptor 3 mutations in bladder cancer and voided urine. Clin Cancer Res. 2005;11(21):7743-8.

86. Tilki D, Burger M, Dalbagni G, Grossman HB, Hakenberg OW, Palou J, et al. Urine markers for detection and surveillance of non-muscle-invasive bladder cancer. Eur Urol. 2011; 60(3):484-92.

87. Urquidi V, Rosser CJ, Goodison S. Molecular diagnostic trends in urological cancer: biomarkers for non-invasive diagnosis. Curr Med Chem. 2012;19(22):3653-63.

88. von Knobloch R, Hegele A, Brandt H, Olbert P, Heidenreich A, Hofmann R. Serum DNA and urine DNA alterations of urinary transitional cell bladder carcinoma detected by fluorescent microsatellite analysis. Int J Cancer. 2001;94(1):67-72.

89. Roupret M, Hupertan V, Yates DR, Comperat E, Catto JW, Meuth M, et al. A comparison of the performance of microsatellite and methylation urine analysis for predicting the recurrence of urothelial cell carcinoma, and definition of a set of markers by Bayesian network analysis. BJU Int. 2008;101(11):1448-53.

90. Kompier LC, Lurkin I, van der Aa MN, van Rhijn BW, van der Kwast TH, Zwarthoff EC. FGFR3, HRAS, KRAS, NRAS and PIK3CA mutations in bladder cancer and their potential as 
biomarkers for surveillance and therapy. PLoS One. 2010;5(11):e13821.

91. van der Aa MN, Zwarthoff EC, Steyerberg EW, Boogaard MW, Nijsen Y, van der Keur KA, et al. Microsatellite analysis of voided-urine samples for surveillance of low-grade non-muscleinvasive urothelial carcinoma: feasibility and clinical utility in a prospective multicenter study (Cost-Effectiveness of Follow-Up of Urinary Bladder Cancer trial [CEFUB]). Eur Urol. 2009;55(3):659-67.

92. Zuiverloon TC, van der Aa MN, van der Kwast TH, Steyerberg EW, Lingsma HF, Bangma CH, et al. Fibroblast growth factor receptor 3 mutation analysis on voided urine for surveillance of patients with low-grade non-muscle-invasive bladder cancer. Clin Cancer Res. 2010;16(11):3011-8.

93. Chan MW, Chan LW, Tang NL, Tong JH, Lo KW, Lee TL, et al. Hypermethylation of multiple genes in tumor tissues and voided urine in urinary bladder cancer patients. Clin Cancer Res. 2002;8(2):464-70.

94. Friedrich MG, Weisenberger DJ, Cheng JC, Chandrasoma S, Siegmund KD, Gonzalgo ML, et al. Detection of methylated apoptosis-associated genes in urine sediments of bladder cancer patients. Clin Cancer Res. 2004;10(22):7457-65.

95. Dulaimi E, Uzzo RG, Greenberg RE, Al-Saleem T, Cairns P. Detection of bladder cancer in urine by a tumor suppressor gene hypermethylation panel. Clin Cancer Res. 2004;10(6):1887-93.

96. Renard I, Joniau S, van Cleynenbreugel B, Collette C, Naome C, Vlassenbroeck I, et al. Identification and validation of the methylated TWIST1 and NID2 genes through real-time methylation-specific polymerase chain reaction assays for the noninvasive detection of primary bladder cancer in urine samples. Eur Urol. 2010;58(1):96-104.

97. Hoque MO, Begum S, Topaloglu O, Chatterjee A, Rosenbaum E, Van Criekinge W, et al. Quantitation of promoter methylation of multiple genes in urine DNA and bladder cancer detection. J Natl Cancer Inst. 2006;98(14):996-1004.

98. Reinert T. Methylation markers for urine-based detection of bladder cancer: the next generation of urinary markers for diagnosis and surveillance of bladder cancer. Adv Urol. 2012;2012:503271.

99. Phe V, Cussenot O, Roupret M. Interest of methylated genes as biomarkers in urothelial cell carcinomas of the urinary tract. BJU Int. 2009; 104(7):896-901.

100. Scher MB, Elbaum MB, Mogilevkin Y, Hilbert DW, Mydlo JH, Sidi AA, et al. Detecting DNA methylation of the BCL2, CDKN2A and NID2 genes in urine using a nested methylation specific polymerase chain reaction assay to predict bladder cancer. J Urol. 2012;188(6):2101-7.

101. Chung W, Bondaruk J, Jelinek J, Lotan Y, Liang S, Czerniak B, et al. Detection of bladder cancer using novel DNA methylation biomarkers in urine sediments. Cancer Epidemiol Biomarkers Prev. 2011;20(7):1483-91.

102. Costa VL, Henrique R, Danielsen SA, Eknaes M, Patricio P, Morais A, et al. TCF21 and PCDH17 methylation: an innovative panel of biomarkers for a simultaneous detection of urological cancers. Epigenetics. 2011;6(9):1120-30.

103. Catto JW, Alcaraz A, Bjartell AS, De Vere White R, Evans CP, Fussel S, et al. MicroRNA in prostate, bladder, and kidney cancer: a systematic review. Eur Urol. 2011;59(5):671-81.

104. Dyrskjot L, Ostenfeld MS, Bramsen JB, Silahtaroglu AN, Lamy $\mathrm{P}$, Ramanathan R, et al. Genomic profiling of microRNAs in bladder cancer: miR-129 is associated with poor outcome and promotes cell death in vitro. Cancer Res. 2009;69(11):4851-60.

105. Han Y, Chen J, Zhao X, Liang C, Wang Y, Sun L, et al. MicroRNA expression signatures of bladder cancer revealed by deep sequencing. PLoS One. 2011;6(3):e18286.
106. Yun SJ, Jeong P, Kim WT, Kim TH, Lee YS, Song PH, et al. Cell-free microRNAs in urine as diagnostic and prognostic biomarkers of bladder cancer. Int J Oncol. 2012;41(5):1871-8.

107. Snowdon J, Boag S, Feilotter H, Izard J, Siemens DR. A pilot study of urinary microRNA as a biomarker for urothelial cancer. Can Urol Assoc J. 2012;15:1-5.

108. Puerta-Gil P, Garcia-Baquero R, Jia AY, Ocana S, AlvarezMugica M, Alvarez-Ossorio JL, et al. miR-143, miR-222, and miR-452 are useful as tumor stratification and noninvasive diagnostic biomarkers for bladder cancer. Am J Pathol. 2012;180(5):1808-15.

109. Yamada Y, Enokida H, Kojima S, Kawakami K, Chiyomaru T, Tatarano S, et al. MiR-96 and miR-183 detection in urine serve as potential tumor markers of urothelial carcinoma: correlation with stage and grade, and comparison with urinary cytology. Cancer Sci. 2011;102(3):522-9.

110. Hanke M, Hoefig K, Merz H, Feller AC, Kausch I, Jocham D, et al. A robust methodology to study urine microRNA as tumor marker: microRNA-126 and microRNA-182 are related to urinary bladder cancer. Urol Oncol. 2010;28(6):655-61.

111. Miah S, Dudziec E, Drayton RM, Zlotta AR, Morgan SL, Rosario DJ, et al. An evaluation of urinary microRNA reveals a high sensitivity for bladder cancer. $\mathrm{Br}$ J Cancer. 2012; 107(1):123-8.

112. Adam L, Wszolek MF, Liu CG, Jing W, Diao L, Zien A, et al. Plasma microRNA profiles for bladder cancer detection. Urol Oncol. 2012 [Epub ahead of print].

113. Sanchez-Carbayo M, Socci ND, Lozano J, Saint F, CordonCardo C. Defining molecular profiles of poor outcome in patients with invasive bladder cancer using oligonucleotide microarrays. J Clin Oncol. 2006;24(5):778-89.

114. Blaveri E, Simko JP, Korkola JE, Brewer JL, Baehner F, Mehta $\mathrm{K}$, et al. Bladder cancer outcome and subtype classification by gene expression. Clin Cancer Res. 2005;11(11):4044-55.

115. Dyrskjot L, Zieger K, Real FX, Malats N, Carrato A, Hurst C, et al. Gene expression signatures predict outcome in non-muscle-invasive bladder carcinoma: a multicenter validation study. Clin Cancer Res. 2007;13(12):3545-51.

116. Als AB, Dyrskjot L, von der Maase H, Koed K, Mansilla F, Toldbod HE, et al. Emmprin and survivin predict response and survival following cisplatin-containing chemotherapy in patients with advanced bladder cancer. Clin Cancer Res. 2007;13(15 Pt 1):4407-14.

117. Zieger K, Dyrskjot L, Wiuf C, Jensen JL, Andersen CL, Jensen $\mathrm{KM}$, et al. Role of activating fibroblast growth factor receptor 3 mutations in the development of bladder tumors. Clin Cancer Res. 2005;11(21):7709-19.

118. Holyoake A, O'Sullivan P, Pollock R, Best T, Watanabe J, Kajita Y, et al. Development of a multiplex RNA urine test for the detection and stratification of transitional cell carcinoma of the bladder. Clin Cancer Res. 2008;14(3):742-9.

119. O'Sullivan P, Sharples K, Dalphin M, Davidson P, Gilling P, Cambridge $\mathrm{L}$, et al. A multigene urine test for the detection and stratification of bladder cancer in patients presenting with hematuria. J Urol. 2012;188(3):741-7.

120. Hanke M, Kausch I, Dahmen G, Jocham D, Warnecke JM. Detailed technical analysis of urine RNA-based tumor diagnostics reveals ETS2/urokinase plasminogen activator to be a novel marker for bladder cancer. Clin Chem. 2007;53(12):2070-7.

121. Eissa S, Swellam M, Shehata H, El-Khouly IM, El-Zayat T, El-Ahmady O. Expression of HYAL1 and survivin RNA as diagnostic molecular markers for bladder cancer. J Urol. 2010;183(2):493-8.

122. Christoph F, Weikert S, Wolff I, Schostak M, Tabiti K, Muller $\mathrm{M}$, et al. Urinary cytokeratin 20 mRNA expression has the 
potential to predict recurrence in superficial transitional cell carcinoma of the bladder. Cancer Lett. 2007;245(1-2):121-6.

123. Pu XY, Wang ZP, Chen YR, Wang XH, Wu YL, Wang HP. The value of combined use of survivin, cytokeratin 20 and mucin 7 mRNA for bladder cancer detection in voided urine. J Cancer Res Clin Oncol. 2008;134(6):659-65.

124. Rosser CJ, Liu L, Sun Y, Villicana P, McCullers M, Porvasnik $\mathrm{S}$, et al. Bladder cancer-associated gene expression signatures identified by profiling of exfoliated urothelia. Cancer Epidemiol Biomarkers Prev. 2009;18(2):444-53.

125. Mengual L, Burset M, Ribal MJ, Ars E, Marin-Aguilera M, Fernandez $M$, et al. Gene expression signature in urine for diagnosing and assessing aggressiveness of bladder urothelial carcinoma. Clin Cancer Res. 2010;16(9):2624-33.

126. Urquidi V, Goodison S, Cai Y, Sun Y, Rosser CJ. A candidate molecular biomarker panel for the detection of bladder cancer. Cancer Epidemiol Biomarkers Prev. 2012;21(12):2149-58.

127. Sun Y, Todorovic S, Goodison S. Local-learning-based feature selection for high-dimensional data analysis. IEEE Trans Pattern Anal Mach Intell. 2010;32(9):1610-26.

128. Sun Y, Goodison S, Li J, Liu L, Farmerie W. Improved breast cancer prognosis through the combination of clinical and genetic markers. Bioinformatics. 2007;23(1):30-7.

129. Sun Y, Goodison S. Optimizing molecular signatures for predicting prostate cancer recurrence. Prostate. 2009;69(10): 1119-27.

130. Malo TL, Lipkus I, Wilson T, Han HS, Acs G, Vadaparampil ST. Treatment choices based on OncotypeDx in the breast oncology care setting. J Cancer Epidemiol. 2012;2012:941495.

131. Nam RK, Kattan MW, Chin JL, Trachtenberg J, Singal R, Rendon R, et al. Prospective multi-institutional study evaluating the performance of prostate cancer risk calculators. J Clin Oncol. 2011;29(22):2959-64.

132. Abogunrin F, O'Kane HF, Ruddock MW, Stevenson M, Reid CN, O'Sullivan JM, et al. The impact of biomarkers in multivariate algorithms for bladder cancer diagnosis in patients with hematuria. Cancer. 2012;118(10):2641-50.

133. Kelly JD, Dudderidge TJ, Wollenschlaeger A, Okoturo O, Burling $\mathrm{K}$, Tulloch $\mathrm{F}$, et al. Bladder cancer diagnosis and identification of clinically significant disease by combined urinary detection of Mcm5 and nuclear matrix protein 22. PLoS One. 2012;7(7):e40305.

134. Margel D, Pesvner-Fischer M, Baniel J, Yossepowitch O, Cohen IR. Stress proteins and cytokines are urinary biomarkers for diagnosis and staging of bladder cancer. Eur Urol. 2011; 59(1):113-9.

135. Celis JE, Rasmussen HH, Vorum H, Madsen P, Honore B, Wolf $\mathrm{H}$, et al. Bladder squamous cell carcinomas express psoriasin and externalize it to the urine. J Urol. 1996;155(6):2105-12.

136. Chen CL, Lai YF, Tang P, Chien KY, Yu JS, Tsai CH, et al. Comparative and targeted proteomic analyses of urinary microparticles from bladder cancer and hernia patients. J Proteome Res. 2012;11(12):5611-29.

137. Feldman AS, Banyard J, Wu CL, McDougal WS, Zetter BR. Cystatin $\mathrm{B}$ as a tissue and urinary biomarker of bladder cancer recurrence and disease progression. Clin Cancer Res. 2009;15(3):1024-31.

138. Schwamborn K, Krieg RC, Grosse J, Reulen N, Weiskirchen R, Knuechel R, et al. Serum proteomic profiling in patients with bladder cancer. Eur Urol. 2009;56(6):989-96.

139. Rasmussen HH, Orntoft TF, Wolf H, Celis JE. Towards a comprehensive database of proteins from the urine of patients with bladder cancer. J Urol. 1996;155(6):2113-9.

140. Irmak S, Tilki D, Heukeshoven J, Oliveira-Ferrer L, Friedrich $\mathrm{M}$, Huland H, et al. Stage-dependent increase of orosomucoid and zinc-alpha(2)-glycoprotein in urinary bladder cancer. Proteomics. 2005;5(16):4296-304.

141. Orenes-Piñero E, Corton M, Gonzalez-Peramato P, Algaba F, Casal I, Serrano A, et al. Searching urinary tumor markers for bladder cancer using a two-dimensional differential gel electrophoresis (2D-DIGE) approach. J Proteome Res. 2007; 6(11):4440-8.

142. Saito M, Kimoto M, Araki T, Shimada Y, Fujii R, Oofusa K, et al. Proteome analysis of gelatin-bound urinary proteins from patients with bladder cancers. Eur Urol. 2005;48(5):865-71.

143. Vlahou A, Schellhammer PF, Mendrinos S, Patel K, Kondylis FI, Gong L, et al. Development of a novel proteomic approach for the detection of transitional cell carcinoma of the bladder in urine. Am J Pathol. 2001;158(4):1491-502.

144. Holterman DA, Diaz JI, Blackmore PF, Davis JW, Schellhammer PF, Corica A, et al. Overexpression of alpha-defensin is associated with bladder cancer invasiveness. Urol Oncol. 2006;24(2):97-108.

145. Theodorescu D, Wittke S, Ross MM, Walden M, Conaway M, Just I, et al. Discovery and validation of new protein biomarkers for urothelial cancer: a prospective analysis. Lancet Oncol. 2006; 7(3):230-40.

146. Chen YT, Chen CL, Chen HW, Chung T, Wu CC, Chen CD, et al. Discovery of novel bladder cancer biomarkers by comparative urine proteomics using iTRAQ technology. J Proteome Res. 2010;9(11):5803-15.

147. Yang N, Feng S, Shedden K, Xie X, Liu Y, Rosser CJ, et al. Urinary glycoprotein biomarker discovery for bladder cancer detection using LC/MS-MS and label-free quantification. Clin Cancer Res. 2011;17(10):3349-59.

148. Feng S, Yang N, Pennathur S, Goodison S, Lubman DM. Enrichment of glycoproteins using nanoscale chelating concanavalin A monolithic capillary chromatography. Anal Chem. 2009;81(10):3776-83.

149. Urquidi V, Goodison S, Kim J, Chang M, Dai Y, Rosser CJ. Vascular endothelial growth factor, carbonic anhydrase 9, and angiogenin as urinary biomarkers for bladder cancer detection. Urology. 2012;79(5):1185, e1-6.

150. Urquidi V, Goodison S, Ross S, Chang M, Dai Y, Rosser CJ. Diagnostic potential of urinary alpha1-antitrypsin and apolipoprotein $\mathrm{E}$ in the detection of bladder cancer. $\mathrm{J}$ Urol. 2012;188(6):2377-83.

151. Urquidi V, Kim J, Chang M, Dai Y, Rosser CJ, Goodison S. CCL18 in a multiplex urine-based assay for the detection of bladder cancer. PLoS One. 2012;7(5):e37797.

152. Goodison S, Chang M, Dai Y, Urquidi V, Rosser CJ. A multianalyte assay for the non-invasive detection of bladder cancer. PLoS One. 2012;7(10):e47469.

153. Hyndman ME, Mullins JK, Bivalacqua TJ. Metabolomics and bladder cancer. Urol Oncol. 2011;29(5):558-61.

154. Issaq HJ, Nativ O, Waybright $T$, Luke B, Veenstra TD, Issaq EJ, et al. Detection of bladder cancer in human urine by metabolomic profiling using high performance liquid chromatography/mass spectrometry. J Urol. 2008;179(6):2422-6.

155. Pasikanti KK, Esuvaranathan K, Ho PC, Mahendran R, Kamaraj $\mathrm{R}, \mathrm{Wu} \mathrm{QH}$, et al. Noninvasive urinary metabonomic diagnosis of human bladder cancer. J Proteome Res. 2010;9(6):2988-95.

156. Putluri N, Shojaie A, Vasu VT, Vareed SK, Nalluri S, Putluri V, et al. Metabolomic profiling reveals potential markers and bioprocesses altered in bladder cancer progression. Cancer Res. 2011;71(24):7376-86.

157. Cao M, Zhao L, Chen H, Xue W, Lin D. NMR-based metabolomic analysis of human bladder cancer. Anal Sci. 2012; 28(5):451-6. 